\title{
Methodological Proposal for the Elaboration of a Tourist Potential Index Applied to Historical Heritage
}

\author{
Calderón Puerta ${ }^{1}$, Diego Manuel $^{1 *}$, Arcila Garrido ${ }^{1}$, Manuel $^{1}$, López Sánchez ${ }^{2}$, José Antonio ${ }^{2}$ \\ ${ }^{1}$ Department of History Geography and Philosophy, University of Cádiz, Cádiz 11003, Spain \\ ${ }^{2}$ INDESS, University of Cádiz (Spain), Jerez de la Frontera 11405, Spain
}

Corresponding Author Email: diego.calderonpu@alum.uca.es

https://doi.org/10.18280/ijsdp.150305

Received: 9 July 2019

Accepted: 17 January 2020

\section{Keywords:}

tourist potential, geographic information system, historical heritage, middle ages, cultural tourism

\begin{abstract}
The proposal and development of tourism projects need previous studies that demonstrate their potential, facilitate the analysis of data and decision making. Since the expansion of tourism in the 1960s, different methodologies have been developed that have sought to study the capabilities of the territories and, in turn, have offered a theoretical framework that supports their results. On the one hand, the objective of this work is to analyze existing models of potentiality and their evolution, and on the other hand, offer an index of potentiality calculation that takes into account physical and human aspects and pay attention to late medieval heritage of the province of Cádiz (Spain).
\end{abstract}

\section{INTRODUCTION}

Tourism is currently one of the most important economic sectors in the developed world. The relevance of the sector is reflected in its contribution to GDP by $11.2 \%$ in 2018 in Spain [1].

Since the expansion of this sector in the 1960s it has been necessary to carry out studies that would allow knowing the tourist potential of an area, in order to promote tourism and know the strategies and measures necessary to consolidate and develop this economic sector.

In this sense, a theoretical framework has been developed [2-5], that has incorporated methodological proposals, which have become more complex as these studies were developed.

The objective of this work is first, to propose a concept of potentiality and, in turn, to create a system that allows evaluating the tourist potential of a territory. Secondly, that system will be applied in the province of Cádiz (Spain), highlighting the late medieval heritage existing in the region.

We start from the hypothesis that despite the existence of various potential indicators, the design must be improved, so that the inclusion and valuation of heritage assets have a greater weight in the final result.

From the point of view of the methodology used, in a first phase an integral analysis of the bibliography and studies related to the state of the art and the region under study has been carried out. The second phase consisted of the compilation of all the data that take into consideration all those variables that affect tourist activity, relating them to each other and, subsequently, elaborating a calculation model of tourism potential. This information comes from the statistical institute of Andalusia and presents the lack of updating as the main problem, although they have been taken as reference when there are no other more recent sources.

The data resulting from this formulation has been systematically introduced into a geographic information program (GIS), specifically Arcgis 10.1, which facilitates the analysis and mapping of the indicators.

With all of this, we intend to obtain results that reflect the strengths and weaknesses of the municipalities of the region, as well as to know the tourist possibilities of the Andalusian low-medieval heritage.

\section{THE CONCEPT OF POTENTIAL}

As previously mentioned, studies of tourism potential have their origin in the takeoff of tourism as an economic sector in the 1960s. The importance of knowing the existing resources highlights the interest of authors and institutions to provide models and definitions of potentiality.

The potential term according to the Cambridge Dictionary [6] refers to a quality or element that is "able to develop into something in the future when the necessary conditions exist". The reading of the concept itself indicates that power or potentiality is a capacity that has an element in itself that does not develop until concrete actions are taken for it.

Applying this idea to tourism, we understand that the tourism potential of a region requires, in the first place, an evaluation of its capabilities. This analysis of variables is a process that we could synthesize according to the opinion of Zimmer and Grassman [7] by which the local tourism potential involves three fundamental phases; analysis of the situation, diagnosis and define the strategy to follow. The need for evaluation and assessment is very present in the concept of potential in this way, SECTUR [8] highlighted the need for "any area that considers developing or expanding its tourism must carefully evaluate its tourism resources", and in turn Ritchie and Crouch [9] insists on analyzing "The main resources and attractions: Physiography and climate, culture and history, market ties, mix of special events activities, entertainment, superstructure, as well as support factors and 
resources: Accessibility, facilitating resources, hospitality, initiative and political will".

Therefore, it is understood that the potentiality is the result of the establishment of a causal relationship between the evaluated variables and the subsequent tourist use. In this sense in the words of Maas [10] "the tourism potential of a region depends on the valuation that is made about its resources, as well as the level of structuring its attractions in tourism products".

The analysis of a methodology that allows knowing the tourist possibilities of an area or region, is valid not only to condition the tourist use but also, to propose a "rigorous evaluation of supply, demand, market trends and competences" (LEADER II). The study of potential supply and demand is included in LEADER II and followed in later proposals such as SECTUR [8] or Covarrubias [11]. In this way it is necessary to understand how market trends are articulated to minimize the risk of investments and propose the optimal use of them.

Taking into account the different definitions, we can understand tourist potentiality as an exhaustive analysis of all those elements that influence tourism activity (climate, landscape, relief, communications, infrastructures, policies, material and immaterial heritage, supply, demand, etc.). Analyzed together, they allow obtaining data and drawing conclusions about the tourist capacity of an area or region.

The concept of potentiality must be open and dynamic, since it has to be able to propose a methodology that allows calculating the variables that affect the trends of a sector in constant transformation.

Given the characteristics of the potentiality concept, different techniques have been developed that have allowed the studies to be elaborated, according to their needs or the interest of the authors.

\section{TECHNIQUES TO EVALUATE THE TOURIST POTENTIAL}

All potential studies elaborate their methodology based on an inventory or selection of variables depending on the tourist resources. One of the first inventory methodologies was proposed by the OAS (Organization of American States) in 1978. It understands that the potential is measured in the classification and inventory of attractive resources, infrastructure and equipment [12]. This inventory is an obligatory process since, an analysis of the tourism of a region supposes in the first place to know the availability of resources.

Once the variables are known, different tools are applied to determine the tourist potential. In this way we find models of multivariate statistics, consisting of "the analysis of data that studies, analyzes, represents and interprets the data that result from observing more than one statistical variable on a sample of individuals." [13]. In this sense, this model allows reducing the analysis of multiple data and variables by presenting them in a simpler way, without losing information about them.

With regard to multicriteria evaluation, it "includes a set of techniques that allow evaluating various alternatives of choice in light of multiple criteria and priorities" [10]. In this way the data obtained allows choosing the best choice within a range of alternatives in an environment of competing criteria and conflict [14].

On the other hand, multiple response models, consisting of the fact that the surveyed sample selects one or several options from a list for subsequent analysis, have "the fundamental advantage of maximizing the information obtained from each question by the respondent, as the latter expresses his opinion on all the phrases contained in each question, and therefore, maximizes the accuracy, validity and discriminant capacity of this attitudinal measure [15].

With respect to the Pairwise technique, it is a method that allows comparing variables so that "candidate solutions can be classified as a basis for the selection of optimal solutions" [16]. In this sense, the methodology of pairs facilitates the annotation of all the possible combinations of two factors, thus reducing the factors to be analyzed to obtain the errors existing in the combinations.

Finally, the geographical information systems encompassed within the territorial information system (SIT) must be highlighted [17]. The application of these to tourism is possible thanks to the fact that they allow "to collect store and modify information, in order to generate a global vision of the tourist space" [18]. Therefore, GIS facilitate the interaction of the variables that affect tourism (communications, resources, hotels etc.), obtaining conclusions from the analysis of their spatial representation.

From the analysis of the evolution of the most outstanding potential methods (Table 1), it can be deduced that the complexity of their calculation has been increasing over the years. This reality is explained by the fact that tourism is a dynamic economic sector in constant evolution and, therefore, the different proposals have been adapted to those variables that condition tourism activity and, in turn, have implemented new tools for tourism analysis.

Table 1. Main methodologies of tourist potential (Source: author's own research)

\begin{tabular}{|c|c|}
\hline Technique & Main feature \\
\hline Multivariate & Compress the data and variables for a simpler \\
\hline $\begin{array}{l}\text { Statistics. } \\
\text { Multicriteria } \\
\text { evaluation. }\end{array}$ & $\begin{array}{l}\text { Represents the various possible alternatives } \\
\text { facilitating the selection of them. }\end{array}$ \\
\hline $\begin{array}{l}\text { Multiple } \\
\text { response model. }\end{array}$ & $\begin{array}{l}\text { Lets draw conclusions from surveys with } \\
\text { several options }\end{array}$ \\
\hline Pairwise. & $\begin{array}{l}\text { Analyze two variables by combining them to } \\
\text { obtain the errors of them }\end{array}$ \\
\hline GIS & $\begin{array}{l}\text { It represents in the space the incident factors } \\
\text { in tourism, facilitating the analysis of their } \\
\text { interaction }\end{array}$ \\
\hline
\end{tabular}

\section{EVOLUTION OF POTENTIALITY STUDIES}

Before explaining the models of potentiality, it is obligatory to make an allusion to the classification of the work of evaluation of tourist resources made by Dosso and Mantero in 1997 [19]. In this way we find analytical studies, which start from a descriptive phrase for later, applying various techniques, studying the elements and factors that condition tourism. For its part, the evaluation from the economic point of view, should analyze the tourist offer of the territory to be studied and its subsequent interaction with the demand. Finally, the studies that advocate the understanding of the landscape take into account the characteristics of the landscape and its capacity to host a tourism development.

The first studies on the tourist potential take as main variable the climate analysis thesis defended by Hungles 
(1967) and Mieczkowski among others. The climate itself "... creates environmental conditions that make it possible, hinder or prevent human settlement. Tourism as an activity of man follows these guidelines: the climate becomes a tourist location factor (natural environmental factor) at the moment in which it intervenes in the process of functionality of a territory, whatever its scale" [20]. Undoubtedly, climate is a condition for tourism and explains, among other things, the existence of sun and beach tourism and the seasonality of the sector in some regions. However, one should not fall into a deterministic conception of this factor, since tourism depends on the interaction of geographic, economic, political, cultural factors, among others.

Another of the variables that have been taken into consideration to address the potential has been the use of landscape by Warzynska [3]. In this sense, landscape resources "are the result of a secular - and sometimes very delicate - equilibrium between nature and human work, a balance that is at the base of the rich regional differentiation of the geographical space" [21].

In these first studies we observed that the variables proposed by the authors are basic elements that condition any man-made activity. Subsequent studies and proposals emphasize the application of different techniques and tools that allow a more exhaustive spatial analysis.

Table 2. Summary of potentiality proposals (Source: author's own research)

\begin{tabular}{|c|c|c|}
\hline Year & Author & Proposed methodology \\
\hline 1967 & Mieczkowski & $\begin{array}{l}\text { Analysis of the climate, as an } \\
\text { element that conditions all } \\
\text { human activity. }\end{array}$ \\
\hline 1974 & Warzynska & $\begin{array}{c}\text { Detailed study of the landscape } \\
\text { and its capacity for tourism } \\
\text { development. }\end{array}$ \\
\hline 1978 & OEA & $\begin{array}{l}\text { Inventory of all the elements that } \\
\text { are the object of tourist use. } \\
\text { Tourist quality based on the }\end{array}$ \\
\hline 1992 & Leno & $\begin{array}{c}\text { quantity and quality of tourist } \\
\text { resources. }\end{array}$ \\
\hline 2003 & Padín & $\begin{array}{l}\text { Similar to the method proposed } \\
\text { by Leno. }\end{array}$ \\
\hline 2006 & Reyes y Sánchez & $\begin{array}{c}\text { Based on Leno's methodological } \\
\text { basis, environmental variables } \\
\text { take on a greater role }\end{array}$ \\
\hline 2004 & LEADER II & $\begin{array}{l}\text { Study divided into two phases; } \\
\text { analysis and diagnosis }\end{array}$ \\
\hline 2005 & SECTUR & $\begin{array}{l}\text { Take reference to the proposal of } \\
\text { LEADER II }\end{array}$ \\
\hline $\begin{array}{l}2006- \\
2011\end{array}$ & $\begin{array}{l}\text { Vargas and } \\
\text { Acebedo and } \\
\text { others }\end{array}$ & $\begin{array}{l}\text { Study of supply and demand as a } \\
\text { condition of potential }\end{array}$ \\
\hline 2011 & Cerezo & $\begin{array}{l}\text { Application of GIS to the study } \\
\text { of the territory }\end{array}$ \\
\hline 2013 & $\begin{array}{l}\text { SÁNCHEZ, } \\
\text { SÁNCHEZ y } \\
\text { RENGIFO }\end{array}$ & $\begin{array}{l}\text { Add multiple variables, } \\
\text { alternating tools such as SIG and } \\
\text { Pairwaise }\end{array}$ \\
\hline 2015 & Soria-Leyva & $\begin{array}{l}\text { Classify the potential aspects of a } \\
\text { region based on its attraction and } \\
\text { reception of the demand }\end{array}$ \\
\hline
\end{tabular}

The first work that combines different variables and that has served as the basis for subsequent potential studies is the one carried out by Leno in 1992 on the Castilla channel in Spain [4]. Leno evaluates tourism potential based on the quantity and quality of tourism resources, accessibility or equipment. The influence of this study is visible in the methodologies used by Padín in 2003 for the study of the Galician coast (Spain), Reyes and Sánchez in Oxaca (Mexico) and López in 2006 in Peru, although the latter in its methodology gives more importance to environmental variables [22].

For its part, in the LEADER II programs developed in 2004 for West Cork (Ireland) [23], the potential is carried out in two phases, one of situation analysis and the other of diagnosis of the proposals. It is interesting how SECTUR in 2005 [8] uses a similar methodology also divided into two phases for the evaluation of the Sierra de Nayar (Mexico), consisting of an evaluation and a subsequent proposal of a tourism product.

Subsequent studies are those carried out by Vargas and Acebedo (2006), López (2006), Poggi (2006), Blanco (2008), Acosta (2008) and Pérez (2011) who, as explained above, share the analysis of the offer and demand of the tourist market $[24,25]$.

Among the most recent methodologies is the proposal of Cerezo in 2011 [5] and that of Sánchez, Sánchez and Rengifo in 2013 [12]. In the first of them applied to the Sierra de las Nieves (Malaga) the different variables are introduced in a GIS, developing maps of potentiality. For its part in the 2013 study, it combines tools such as pairwise and the use of GIS, while increasing the number of variables used.

Finally, Soria-Leyva [22], starting from the previous works, proposes a methodology that integrates economic, social and physical factors, so as to facilitate sustainable development.

In all these proposals it is observed that the variables and techniques used have evolved, adapting to the development of the tourism sector (Table 2).

\section{TOURIST INDICATOR PROPOSAL}

This section presents a proposal for an indicator to measure the tourist potential of a territory. In this case we will take into account the different studies mentioned in the previous section, so following the classification of Dosso and Mantero we can say that the proposal is analytical and landscape. This statement is justified in that the purpose of the indicator is to relate the resources that condition the tourism activity (heritage, access, hotels, etc.).

In the scale to which we have worked (municipal) there is no data on tourism demand, which would have served to complete this indicator.

The formula that is going to be used will deal with the calculation of two variables formed by different subvariables. The main variables will be summarized in territorial variables (TV) and visitor variables (VV). In this way, the calculation of potentiality is summarized as follows:

$$
\mathrm{ITP}=(\mathrm{TV}) \sum(\mathrm{VV})=2
$$

The first one (TV) aims to calculate the main factors that make it possible to consider an area as a tourist area. Attending to the same they have selected patrimonial resources (PR), Tourist Resources (TR), the accessibility (AC), hospitality resources (HR), and climate (CL). These subvariables are calculated as follows:

$$
\begin{gathered}
\mathrm{TV}=\left[0.40 *(\mathrm{PR}) \sum 0.15^{*}(\mathrm{TR}) \sum 0.15^{*}(\mathrm{AC}) \sum\right. \\
\left.0.15^{*}(\mathrm{HR}) \sum 0.15^{*}(\mathrm{CL})\right]=1 .
\end{gathered}
$$

We have applied a value of $40 \%$ to the patrimonial 
resources so that the less touristic municipalities are well represented, attending mainly to the late medieval patrimony. To multiply the rest of subvariables we use the same number, since we understand that each of them is equally important and they are also interdependent.

On the other hand, the visitor variable (VV) is comprised by the distance to cities of 100,000 inhabitants (CI) and the reference of the municipality as tourist zone $(\mathrm{V})$, according to the criterion of the INE (National Institute of Statistics).

In each of the variables and subvariables we will perform a weighting between 0 and 1 . In this sense, the municipalities that have the maximum potential exponent will be assigned the value 1 , and those that represent the minimum will be assigned the amount 0 .

Therefore, the intermediate values registered in the remaining municipalities will be calculated taking as reference the values of the municipalities that represent the maximum and the minimum, respectively. Finally, all the data are entered into a database, which facilitates the calculation of the variables.

Calculation of patrimonial resources (PR)

This section includes those assets that are open to the public individually, or integrated into cultural routes and itineraries. In this way, a total of 258 resources can be stabilized, of which $9 \%$ is integrated into routes and itineraries, $11 \%$ is exploited individually and $13 \%$ both on routes and individually.

Calculation of Tourist Resources (TR)

When calculating this variable, it is necessary to analyze what is understood as a tourist resource in the first place. According to the definition of Salinas and Medina [25] are "offers of different types that are prepared to be offered to tourists in the form of activities and services, through the use of different technologies and / or facilities. They must be able to motivate visits to a place for a short time or several days to satisfy an interest or specific need for certain services: recreational, natural, cultural, and others, or a combination of several of them and that also propitiate the best experiences". From the reading of the precept, it can be understood that tourism resources encompass a series of varied elements, which due to their characteristics can be the object of tourist activity.

In the calculation of RT we will take into account the distance to beaches and protected natural spaces within a radius of $50 \mathrm{~km}$ and the ethnographic heritage (record of events declared as ethnographic interest).

Accessibility calculation (AC).

In this section we have taken into consideration, on the one hand, the availability of means of transport in the municipalities themselves (Taxis and bus station) and, on the other hand, the distance to airports, train stations and cruise ports (Puerto de Cádiz) in a $50 \mathrm{~km}$ radius. For this, a buffer has been projected in a GIS, allowing a simpler visualization.

Calculation of hospitality resources (HR).

We will count the hotel beds of each municipality and the number of restaurants. In this sense, the data coming from IDEA (statistical institute of Andalusia) have been taken into account.

Calculation of climatic conditions (CL).

The number of sunshine hours per year has been measured in each of the municipalities. Therefore, the areas with more sun are those that reach the maximum value. The calculation of visitors variables is summarized in:

$$
\mathrm{VV}=\left[0.50 *(\mathrm{CIT}) \sum 0.50 *(\mathrm{~V}) .\right]=1
$$

Calculation of distance to cities (CIT).

With the use of a Buffer, we have weighted the distance of the municipalities to cities with more than 100,000 inhabitants within a radius of $100 \mathrm{~km}$ (CIT).

Calculation of tourist area $(\mathrm{V})$.

We have granted the maximum value of the section to those municipalities that are within a tourist zone or are tourist points according to the criterion of the INE. In this sense, the tourist areas are more or less wide areas (The Costa de la luz de Cádiz) that have a high volume of visitors and that are therefore the object of study in hotel occupancy surveys. For its part, a tourist point, it is a municipality with a consolidated tourism (Tarifa, El Puerto de Santa María, etc.) and it is also used as a reference in the hotel occupation survey.

\subsection{Application to the case study}

Located in the southwest of the Iberian Peninsula, the province of Cádiz, has a population of 1,239,889 inhabitants distributed in 6 regions. It has a Mediterranean climate of moderate rainfall and concentrated in the equinoxes, with mild summers and warm winters, which facilitate the consolidation of the region as a tourist destination.

Despite the importance of tourism we should take into account the seasonal nature of the same and the predominance of sun and beach. The tourist awakening of the area during the decade of 1960 supposed the specialization of the same one in the sun and beach, being this fact cause of an important environmental impact at the same time that the infrastructures and services were improved.
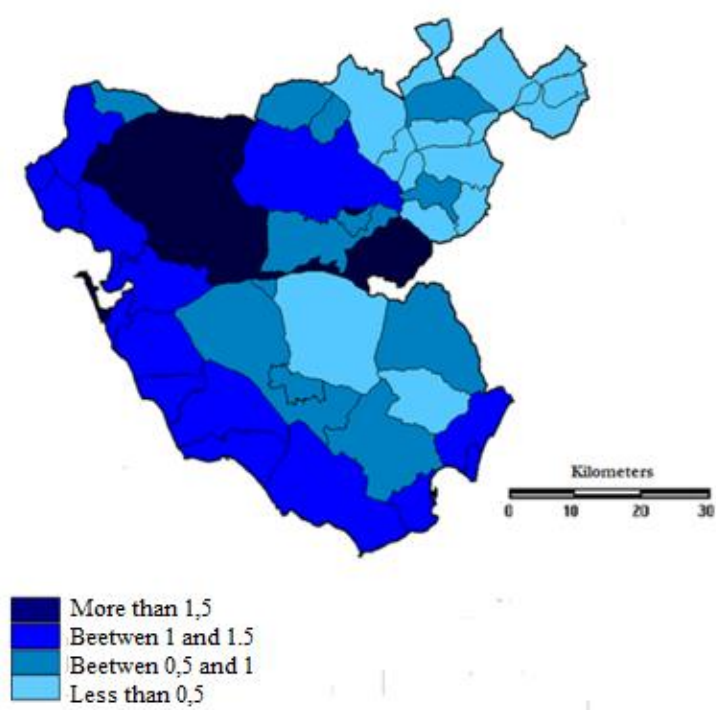

Figure 1. Tourist potential late middle ages (Source: author's own research)

With regard to heritage and cultural wealth, the province of Cádiz has an important legacy resulting from the historical relevance of the area. In this sense the diverse cultures that inhabited the region such as indigenous peoples, Phoenicians, Greeks, Romans, Visigoths, Muslims, Christians up to the configuration of modern states, have left a mark that is materialized in the existence of an abundant and varied heritage that extends to all corners of the Andalusian geography.

The heritage object of study of this work corresponds to those elements belonging to or that have their origin in the Late 
Middle Ages. This heritage is consolidated between the thirteenth and fifteenth centuries with the conquest by the kingdom of Castile of the so-called Kingdom of Seville [26], which until then was in Muslim hands. The establishment of the border between the kingdom of Castile and the Nazari Kingdom of Granada for almost three centuries, meant an economic, social and political configuration that has now been translated into a different regional configuration between low and high Andalusia (Malaga, Jaen, Granada and Almería) and the existence of a rich heritage [27, 28].

After entering the data in a GIS, the results mapped in Figure 1 have been obtained.

\subsection{Results}

The municipalities with the lowest potential index (less than 0.5 ) are located in inland and mountainous areas, which in many cases do not have a developed tourism structure (hotel supply and restoration) or are far from communication routes (Airport or train stations) and cities.

This explains why municipalities such as Alcalá de los Gazules, Olvera or Zahara de la Sierra, which have an important low-medieval legacy, obtain a low tourist potential.

With a potential of 0.5 to 1 , we find municipalities that show better results due to the wealth of the heritage, but also because the proximity to consolidated tourist areas guarantees a better offer and accessibility.

With a result between 1 to 1.5 are all the coastal municipalities and Arcos de la Frontera. We must bear in mind that in this section, there are municipalities that gather a good number of goods late medieval and at the same time have good access and tourism (Sanlúcar de Barrameda, Puerto de Santa María), with others that despite having little heritage obtain good results for its infrastructure and tourist offer (Chiclana de la frontera, Los -barrios, Barbate).

Finally, Jerez de la Frontera and Cádiz have the greatest potential (greater than 1.5). The reasons are identical to those described in the previous section, although we must add the fact that both are important centers at provincial level.

\section{CONCLUSIONS}

With this work we have proposed a methodology for calculating tourism potential, in which the variables that we consider most important and influential in tourism development have been taken into account. From this proposal is included the application to a case study in the municipalities of the province of Cádiz, an area with a consolidated tourism sector. We can obtain the following conclusions:

(1) The existence of indicators that measure tourist potentiality has been studied since the generalization of tourism in 1960s. The different proposals have influenced different variables (climate, existence of resources, etc.) and have contributed or used methodologies that facilitate calculation and decision making. When studying the development of the different methods proposed by organisms and authors we conclude that the potentiality indexes are changeable realities that must attend to the tourism trends [29].

(2) The analysis of the tourism potential of a region, must integrate human and physical aspects, as requirements to take into account when addressing a tourism project.

(3) The proposed method can be extrapolated to other regions and areas, and other tourism resources can be included.
(4) The use of a GIS allows the information to be ordered in databases and its cartographic.

(5) The results obtained can not be considered as definitive. If we aspire to know the potential evolution of a territory, updated data can be included in the variables. On the other hand, it is clear that despite giving a higher value to the goods of the late medieval period, many municipalities that barely have this heritage legacy obtain good results. This is because the accessibility, and the existence of other tourist resources, is a transcendental factor for the development of tourism.

(6) It is evident that in the selected region the heritage is very rich and that therefore there is a potential that is not sufficiently used by the tourism sector.

\section{REFERENCES}

[1] Instituto Nacional de Estadística (INE). Government of Spain.

[2] Mieczkowski, Z. (1985). The tourism climatic index: A method of evaluating world climates for a tourism. The Canadian geographer/ Le Géographe Canadien, 29(3): 220-233. https://doi.org/10.1111/j.15410064.1985.tb00365.x

[3] Warzynska, J. (1974). An evaluation of natural environment resources for the development of tourist functions as exemplified by the Cracow province. PWN, Warszawa-Krakóv.

[4] Leno, F. (1993). Técnicas de Evaluación del Potencial Turístico. Madrid: MICYT, Centro de Publicaciones, D.L.

[5] Cerezo Medina, A., Galacho Jiménez. (2011). A GIS based proposal for evaluating the potential of the territory for ecotourism and adventure tourism activities: An application to Sierra de Las Nieves (Málaga, Spain), Investigaciones Turísticas, 1: 134-147. http://dx.doi.org/10.14198/INTURI2011.1.09

[6] Cambridge Dictionary. Online, https://dictionary.cambridge.org/es/, accessed on 23 Jun. 2019.

[7] Zimmer, P., Grassmann, S. (1997). Evaluar el potencial turístico de un territorio. Observatorio Europeo Leader.

[8] SECTUR. Identificación de potencialidades turísticas en regiones y municipios. Serie 8 de documentos técnicos de competitividad, SECTUR. 2005.

[9] Ritchie, B., Crouch, G.I. (2003). The competitive destination: A sustainable tourism perspective. CABI Publishing, Wallingford.

[10] Maass, F., Osorio García, M., Nava Bernal, G., RegilGarcía, H. (2009). Multicriteria evaluation of tourism resources. Snowy National Park of Toluca. Estudiosy Perspectivas Turísticas, 18(2): 208-226.

[11] Covarrubias, R. (2015). Evaluación del potencial en municipios turísticos a través de metodologías participativas. El caso de los municipios de la zona norte de Colima. Mexico, University of Colima.

[12] Sánchez Martín, J., Sánchez Rivero, M., Rengifo Gallego, J. (2013). Assessment of the potential for rural tourism development. A metodological application in the province of Caceres. GeoFocus. Revista Internacional de Ciencia y Tecnología de la Información Geográfica, 13(1): https://doi.org/10.1080/13683500.2014.978745

[13] Cuadras, C. (2010). Nuevos Métodos de Análisis 
Multivariantes. CMC EDITIONS.

[14] Pietersen, K. (2006). Multiple criteria decision analysis (MCDA): A tool to support sustainable management of groundwater resources in South Africa. Water SA, 32(2): 119-128. 2006. http://dx.doi.org/10.4314/wsa.v32i2.5242

[15] Vázquez Alonso, A., Acevedo Díaz, J. (2006). The multiple response model applied to the evaluation of attitudes about Science, Technology and Society (CTS). I Latin American Congress of Science, Technology, Society and Innovation.

[16] Saaty, T. (1990). The analytic hierarchy process in conflicto management. International Journal of Conflict Management, $1(1)$ : 47-68. https://doi.org/10.1108/eb022672

[17] Ocaña, C., Galacho, F. (2002). A GIS Application Model and multicriteria evaluation to analyze the capacity of the territory in relation to tourist functions. IV Congress "Tourism and information and communications technologies" TURITEC.

[18] Ossa, J., Estrada, G. (2012). The geographic information systems and land use plans in Colombia. Perspectiva Geográfica, 1(16): 247-266.

[19] Dosso, R., Mantero, J. (1997). Técnicas de evaluación de recursos turísticos y paisajes: Hacia una alternativa incluyente. Territorios en redefinición. Lugary Mundo en América Latina. Buenos Aires. Universidad de Buenos Aires, pp. 115-127.

[20] Gómez Martín, B. (2005). Geographical reflection around the climate-tourism binomial. Boletín de la
Asociación de Geógrafos Españoles, (40): 14-134.

[21] Nogue i Font, J. (1992). Tourism landscape perception and territory planning. Estudios Turísticos, 11: 45-54.

[22] Soria-Leyva, E. (2015). Tourist Potential in a Sustainable Approach. An Application Case. Anuario Facultad de Ciencias Económicas y Empresariales, 6: 34-59.

[23] LEADER II., Evaluar el potencial turístico de un territorio. Observatorio Europeo LEADER.

[24] Mikery Gutiérrez, M., Pérez Vázquez, A. (2014). Methods for the analysis of the tourism potential of the rural territory. Revista Mexicana de Ciencias Agrícolas, 9:

$1729-1740$. https://doi.org/10.29312/remexca.v0i9.1060

[25] Salinas Chávez, E., Medina Pérez, N. (2009). The tourist products. Pillars of marketing. Two examples of the historical center of Havana, Cuba. Estudiosy Perspectivas en Turismo, 18(2): 227-242.

[26] González Jiménez, M. (2008). La repoblación del reino de Sevilla en el siglo XIII, Universidad de Sevilla.

[27] Ladero Quesada, M. (2002). La frontera de Granada 1265 1481. Revista de Historia Militar, 1: 49-122.

[28] Reyes, O. (2006). La evaluación de las condiciones naturales para el desarrollo sustentable de la actividad turística en el estado de Oaxaca. México, Facultad de Filosofía y Letras, UNAM.

[29] Blanco López, P. (2015). Inventory of tourism resources as a basis for territorial planning in Zona Altiplano of San Luis Potosi, Mexico. Cuadernos de Turismo, 35: 17-42. https://doi.org/10.6018/turismo.35.221491 